\title{
A new approach to inducing $\mathrm{Ti}^{3+}$ in anatase $\mathrm{TiO}_{2}$ for efficient photocatalytic hydrogen production
}

\author{
Shunhang Wei a, Shuang $\mathrm{Ni}^{\mathrm{b}, *}$, Xiaoxiang Xu a,\# \\ a Shanghai Key Lab of Chemical Assessment and Sustainability, School of Chemical Science and Engineering, Tongji University, Shanghai 200092, China \\ b Science and Technology on Plasma Physics Laboratory, Laser Fusion Research Center, China Academy of Engineering Physics, Mianyang 621900 , \\ Sichuan, China
}

\section{A R T I C L E I N F}

\section{Article history:}

Received 28 September 2017

Accepted 30 October 2017

Published 5 March 2018

\section{Keywords:}

$\mathrm{Ti}^{3+}$

Oxygen vacancy

$\mathrm{TiO}_{2}$

Photocatalyst

Hydrogen production

\begin{abstract}
A B S T R A C T
$\mathrm{Ti}^{3+}$ species and oxygen vacancies were successfully introduced into anatase $\mathrm{TiO}_{2}$ by a simple method. The physicochemical properties of the as-prepared samples were explored by techniques including X-ray diffraction and field emission scanning electron microscopy. The amount of $\mathrm{H}_{2} \mathrm{O}_{2}$ precursor and hydrothermal reaction time were found to affect the formation of the $\mathrm{TiO}_{2}$ nanorod-type microstructure. Possible mechanisms for the formation of this microstructure are proposed on the basis of analytical results, including electron paramagnetic resonance, where parameters such as the amount of $\mathrm{H}_{2} \mathrm{O}_{2}$ and hydrothermal reaction time were adjusted. More importantly, light absorption in the visible light region was strongly affected by the number of oxygen vacancies within the samples. The oxygen vacancy content featured an optimal level for producing the highest photocatalytic hydrogen production activity.
\end{abstract}

(C) 2018, Dalian Institute of Chemical Physics, Chinese Academy of Sciences. Published by Elsevier B.V. All rights reserved.

\section{Introduction}

Hydrogen is considered to be a clean and renewable energy source, which might address global concerns regarding future fossil fuel shortages. Photocatalytic water splitting into hydrogen and oxygen on the surface of a semiconductor is widely accepted to be an ideal means for hydrogen production owing to the inexhaustible nature of solar radiation and the abundance of water on earth [1-6]. Among various photocatalysts, titanium dioxide $\left(\mathrm{TiO}_{2}\right)$ has continued to attract considerable attention because of its superior chemical stability, low-toxicity, and cost effectiveness [7,8]. Nevertheless, drawbacks such as its wide band gap (3.2 eV for anatase) and fast electron-hole recombination rate substantially limit the use of $\mathrm{TiO}_{2}$ practical applications. Considerable efforts have been devoted to modifying $\mathrm{TiO}_{2}$ to improve its light absorption and photocatalytic activity. The doping of heteroatoms (such as $\mathrm{N}$ [9], C [10], Fe [11], S [12]) into $\mathrm{TiO}_{2}$ has successfully been used to enhance the light absorption of $\mathrm{TiO}_{2}$; however, challenges remain as these heteroatoms may act as extra electron-hole recombination centers [13].

After the pioneering work of Chen et al. [14], self-doping $\mathrm{TiO}_{2}$ (i.e., $\mathrm{Ti}^{3+}$ species) might be a promising alternative strategy to modifying this wide band gap semiconductor. Further studies have shown that $\mathrm{Ti}^{3+}$ species and their charge balancing counterpart-oxygen vacancies are responsible for band-gap

\footnotetext{
* Corresponding author. E-mail: nishuang@163.com

\# Corresponding author. Tel/Fax: +86-21-65956919; E-mail: xxxu@tongji.edu.cn

This work was supported by the National Natural Science Foundation of China (21401142), Recruitment Program of Global Youth Experts (1000 plan), and Science \& Technology Commission of Shanghai Municipality (14DZ2261100).

DOI: 10.1016/S1872-2067(17)62968-1 | http://www.sciencedirect.com/science/journal/18722067 | Chin. J. Catal., Vol. 39, No. 3, March 2018
} 
narrowing and the separation of photogenerated electrons and holes [15-17]. Various preparation methods and synthetic techniques have been used to increase the oxygen vacancy concentration in $\mathrm{TiO}_{2}$ including hydrogen plasmas [15], aluminum reduction [16], chemical oxidation [17], and electrochemical reduction [18]. The approach involving $\mathrm{Ti}^{3+}$ in self-doped $\mathrm{TiO}_{2-x}$ is distinct from these methods owing to the simpler and safer procedures (no requirement for the use of hydrogen) and better visible light photocatalytic activity. To date, methods to induce $\mathrm{Ti}^{3+}$ have generally been energy intensive and involved unstable Ti raw materials (such as $\mathrm{TiO}$ [19] and $\mathrm{TiH}_{2}$ [17]). In this context, it is highly desirable to develop an alternative method for preparing $\mathrm{Ti}^{3+}$ self-doped $\mathrm{TiO}_{2}$.

Here, we successfully prepared self-doped $\mathrm{TiO}_{2}$ using metallic $\mathrm{Ti}$ and $\mathrm{H}_{2} \mathrm{O}_{2}$ as raw materials. Our method shows great advantages over previous methods in that the concentration of $\mathrm{Ti}^{3+}$ species and oxygen vacancies can be easily tuned by controlling the amounts of added $\mathrm{H}_{2} \mathrm{O}_{2}$ and the hydrothermal reaction time. The involvement of $\mathrm{H}_{2} \mathrm{O}_{2}$ during the synthesis not only allows control over the dopant concentration but is also critical for controlling the microstructures. Nanorod-type self-doped $\mathrm{TiO}_{2}$ can be synthesized by the addition of appropriate amounts of $\mathrm{H}_{2} \mathrm{O}_{2}$. Possible mechanisms for the formation of such microstructures have been proposed. Photocatalytic hydrogen experiments have confirmed the high photocatalytic activity of self-doped $\mathrm{TiO}_{2}$. The correlation between the catalytic activity and the concentration of $\mathrm{Ti}^{3+}$ species is discussed.

\section{Experimental}

\subsection{Photocatalyst preparation}

$\mathrm{Ti}^{3+}$ self-doped $\mathrm{TiO}_{2}$ was prepared by annealing in a $\mathrm{N}_{2}$ atmosphere after a hydrothermal reaction. In a typical preparation procedure, $0.3 \mathrm{~g}$ of Ti power (99.99\%, Aladdin) was mixed with $20 \mathrm{~mL}$ of water, $8 \mathrm{~g}$ of sodium hydroxide and a certain amount of $\mathrm{H}_{2} \mathrm{O}_{2}$ solution $(30 \%)(0,20,50$, and $100 \mu \mathrm{L})$. The suspension was transferred into an autoclave for the hydrothermal reaction. Various hydrothermal reaction times at 180 ${ }^{\circ} \mathrm{C}$ were used $(12,18,24$, and $30 \mathrm{~h})$. The resultant precipitates were then collected, washed with hydrochloric acid and water until the $\mathrm{pH}$ of the washings was neutral. The obtained precipitates were grinded for approximately $30 \mathrm{~min}$ with an agate pestle and mortar and then calcined at $500{ }^{\circ} \mathrm{C}$ for $3 \mathrm{~h}$. The samples were named according to the calcination atmosphere, the amount of $\mathrm{H}_{2} \mathrm{O}_{2}$ and hydrothermal reaction time. The samples calcined in $\mathrm{N}_{2}$ were designated as 500-0-12, 500-20-12, 500-50-12, 500-100-12, 500-100-18, 500-100-24, and 500-100-30. An uncalcined sample was designated similarly as 100-24 (with $100 \mu \mathrm{L} \mathrm{H}_{2} \mathrm{O}_{2}$ and a hydrothermal reaction time of $24 \mathrm{~h})$.

\subsection{Photocatalytic reactions}

The photocatalytic hydrogen evolution was evaluated in a top-irradiation-type reactor connected to a gas closed circulation and evacuation system (Perfect Light, Labsolar-IIIAG). In a typical experiment, $0.1 \mathrm{~g}$ of the sample powders were dispersed in $100 \mathrm{~mL}$ of aqueous solution containing $10 \%$ methanol by volume. Pt was loaded onto the samples at $1 \mathrm{wt} \%$ by a photo-deposition method: $\mathrm{H}_{2} \mathrm{PtCl}_{6}$ aqueous solution was reduced into Pt nanoparticles over $1 \mathrm{~h}$ under full spectra irradiation [20]. A $300 \mathrm{~W}$ xenon lamp (Perfect Light, PLX-SXE300) was used as a light source. An AM1.5 filter was applied to simulate natural sunlight. The gas component within the reactor was then analyzed using an online gas chromatograph (Techcomp, GC7900) with a TCD detector.

\subsection{Characterization}

Crystal structure was examined by X-ray powder diffraction (XRD) techniques (DX-2700B X-ray Diffractometer, Haoyuan). Raman spectra were collected on an inVia Raman Microscope (Renishaw). The morphologies of the samples were inspected with a field-emission scanning electron microscope (Hitachi S4800). The optical absorption spectra of samples were obtained at room temperature with a UV-Vis spectrophotometer (JASCO-750) and the JASCO software suite. $\mathrm{BaSO}_{4}$ was used as a reference non-absorbing material. The X-ray photoelectron spectra (XPS) measurements were measured on a Thermo ESCALAB 250XI equipped with monochromatized Al $K_{\alpha}$ radiation using $\mathrm{C} 1 s(284.8 \mathrm{eV})$ as the reference. Electron paramagnetic resonance (EPR) spectra were collected with the use of a JES FA200 spectrometer at room temperature.

\section{Results and discussion}

XRD patterns of as-prepared samples are shown in Fig. 1(a). Analysis of these patterns suggested that $100 \mu \mathrm{L}$ of $\mathrm{H}_{2} \mathrm{O}_{2}$ and a hydrothermal reaction time longer than $24 \mathrm{~h}$ were needed to fully convert all the metallic Ti. The subsequent calcination in a $\mathrm{N}_{2}$ atmosphere at $500{ }^{\circ} \mathrm{C}$ was necessary to crystallize the hydrothermal precursors into an anatase phase JCPDS Card no. 21-1272). Raman spectra were recorded to further examine the structure of the as-prepared sample. As shown in Fig. 1(b), five characteristic Raman peaks at 143.2 (Eg), 196 (Eg), 396 (B1g), $515\left(\mathrm{~A}_{1 \mathrm{~g}}\right.$ or $\left.\mathrm{B}_{1 \mathrm{~g}}\right)$ and $637\left(\mathrm{E}_{\mathrm{g}}\right) \mathrm{cm}^{-1}$ emerged for all samples after calcination, assignable to the Raman modes of the anatase phase $[21,22]$. Thus, we confirmed the successful preparation of anatase $\mathrm{TiO}_{2}$ from metallic Ti.

X-ray photoelectron spectroscopy (XPS) was further used to investigate the surface chemistry of the as-prepared samples. As shown in Fig. 2(a), binding energies for the Ti $2 p$ state in the 500-100-12 samples were consistent with typical peaks of $\mathrm{TiO}_{2}$ with Ti $2 p_{3 / 2}(458.43 \mathrm{eV})$ and $2 p_{1 / 2}(464.12 \mathrm{eV})$ peaks $[9,16]$. The $01 s$ state in Fig. 2(b) featured two overlapping peaks: one locating at $529.69 \mathrm{eV}$ was typical for lattice oxygen in $\mathrm{TiO}_{2}$; the other one located at $531.29 \mathrm{eV}$ was assigned to surface $\mathrm{OH}$ groups [15]. Compared with the 100-12 samples (Fig. 2(c) and (d)), there was a small decrease in the binding energy of Ti and $\mathrm{O}$ after calcining the sample in $\mathrm{N}_{2}$ at $500{ }^{\circ} \mathrm{C}$, indicating the importance of the thermal treatment in weakening the bond strength between $\mathrm{Ti}$ and $\mathrm{O}$. Interestingly, signals from elemental Ti were not detected in either of these two samples, 

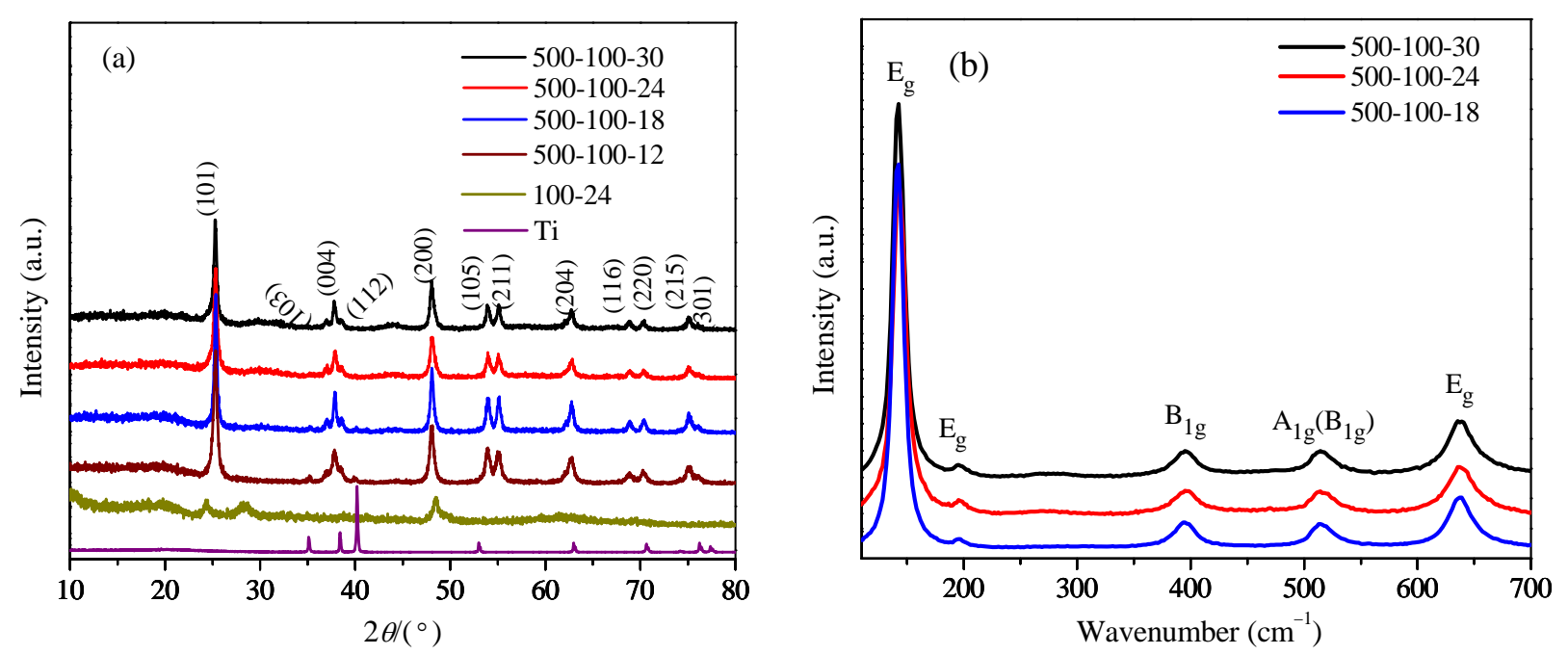

Fig. 1. XRD patterns (a) and Raman spectra (b) of samples.
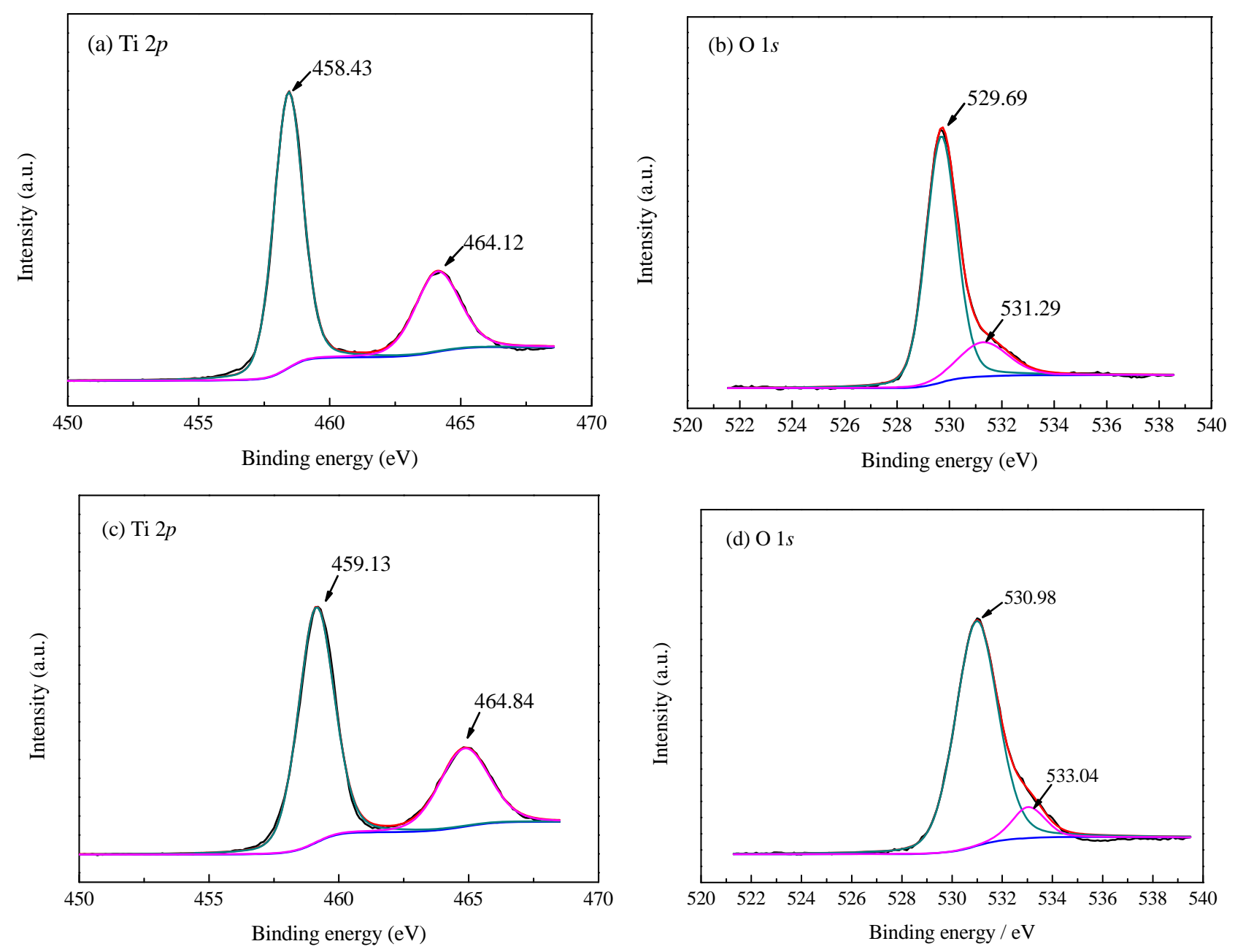

Fig. 2. Ti $2 p$ XPS spectra of 500-100-12 (a) and 100-12 (c), 0 1s XPS spectra of 500-100-12 (b) and 100-12 (d).

likely because of the detection limitations of XPS, which can generally only penetrate to a depth of $1-3 \mathrm{~nm}$ from the surface. High-resolution TEM (HRTEM) images of the 500-100-12 samples (Fig. S1) showed that the distance in the crystal lattices of the outer layer was $0.352 \mathrm{~nm}$, which is consistent with the (101) lattice planes of anatase. The binding energies of Ti in 500-100-24 and 500-100-30 samples were also ascribed to $\mathrm{Ti}^{4+}$ (Fig. S2). For all samples, no $\mathrm{Ti}^{3+}$ peaks were detected by XPS. 

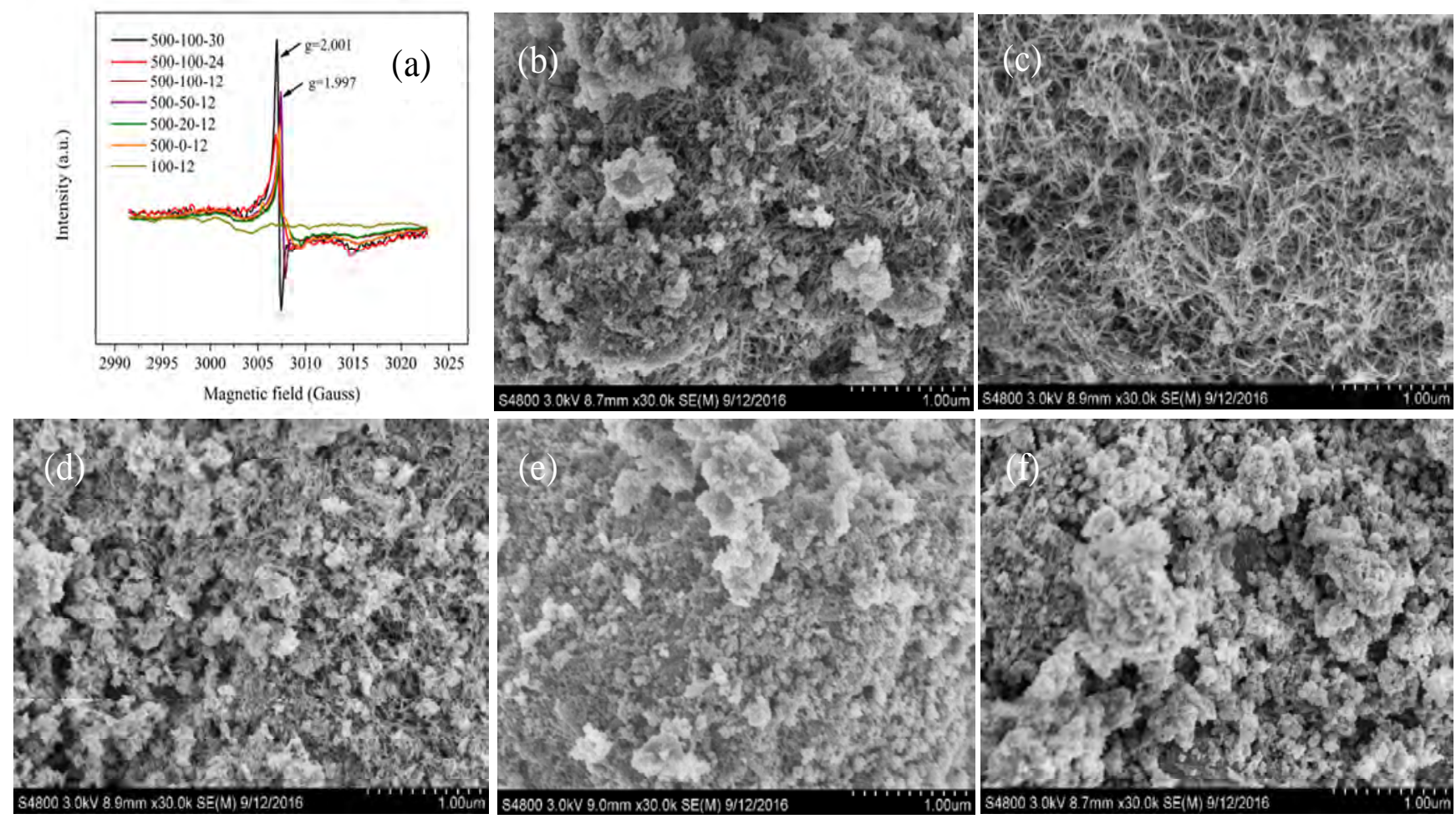

Fig. 3. EPR results (a) of samples, FESEM images of 100-12 (b), 500-100-12 (c), 500-50-12 (d), 500-20-12 (e), and 500-0-12 (f) samples.

Electron paramagnetic resonance (EPR) is a useful technique to detect paramagnetic species owing to its high sensitivity toward unpaired electrons. Notably, the calcined samples exhibited strong responses at g-values of $\sim 2.001$ and $\sim 1.997$ in their EPR spectra (Fig. 3(a)), which could be attributed to surface oxygen vacancies [23,24]. The amount oxygen vacancies appeared to increase as the amount of added $\mathrm{H}_{2} \mathrm{O}_{2}$ was increased and also correlated with the hydrothermal reaction time. However, the uncalcined sample (100-12) did not show oxygen vacancy signals. Notably, few nanorods were formed by the hot alkali method in the 100-12 samples and the nanorods length was short. Conversely, a number of long nanorods were formed in the 500-100-12 samples after calcination, as shown in Fig. 3(b) and (c) (larger version in Fig. S3). In addition, the nanorod structure was hardly found in the 500-20-12 (Fig. 3(e)), 500-0-12 (Fig. 3(f)), 500-100-24 (Fig. S4a), and 500-100-30 (Fig. S4b) samples except for the 500-50-12 (Fig. 3(d)) samples.

The presence of oxygen vacancies may be ascribed to either the reduction of $\mathrm{TiO}_{2}$ by the remaining metallic $\mathrm{Ti}$ or the loss of oxygen by the removal of surface $\mathrm{OH}$ groups. According to XRD results of the uncalcined sample (Fig. S5), the amount of Ti decreased as the hydrothermal reaction progressed and Ti was fully converted with a hydrothermal reaction period of $24 \mathrm{~h}$, implying that the contribution from metallic Ti to the formation of oxygen vacancies should decreased over a long hydrothermal time. However, the opposite trend was found. More oxygen vacancies were found for the sampled subjected to long hydrothermal time. In this regard, the oxygen vacancies might be attributed to the removal of surface $\mathrm{OH}$ groups. This loss of oxygen from Ti-O might be associated with a change of the morphology. We propose the following mechanism. On the basis of the morphology of 500-0-12, 500-20-12, 500-50-12, and $500-100-12$ samples, it is likely that $\mathrm{H}_{2} \mathrm{O}_{2}$ promoted the formation of hydroxyl groups bonded with $\mathrm{Ti}$, such that $\mathrm{Ti}-\mathrm{O}-\mathrm{Ti}$ bonds were generated along one direction through selective dehydration of $\mathrm{Ti}-\mathrm{OH}$ groups in a certain region under the calcination conditions. In other regions, the hydroxyl groups that were not dehydrated could be removed to form oxygen vacancies. On the basis of our EPR results for the 500-100-12, 500-100-24, and 500-100-30 samples, we deduced that an appropriate vacancy defect content enabled dehydration of $\mathrm{Ti}-\mathrm{OH}$ along one direction owing to a change of

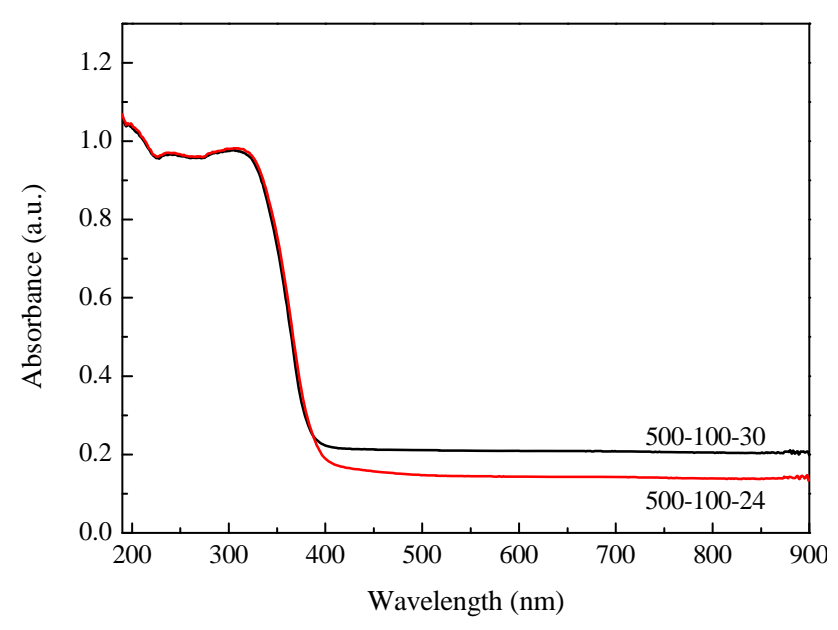

Fig. 4. UV-Vis absorbance spectra of the samples. 

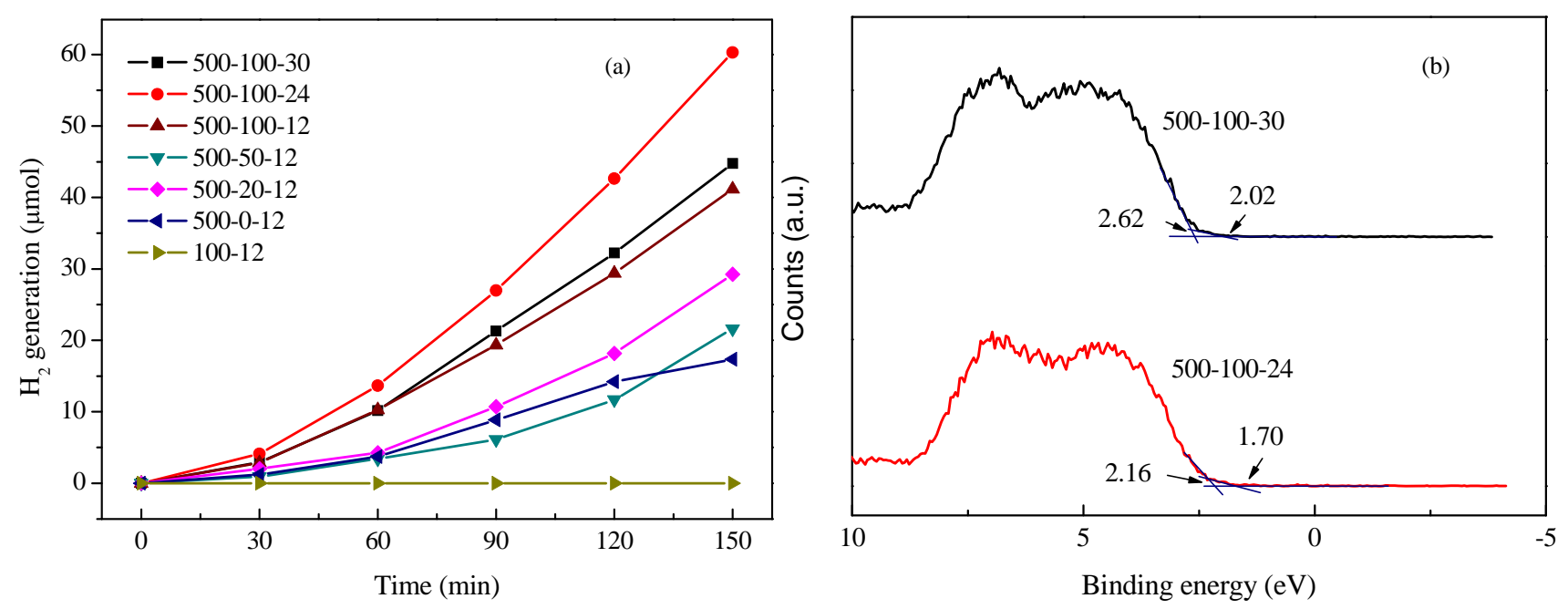

Fig. 5. (a) $\mathrm{H}_{2}$ generation of samples under AM1.5 irradiation, (b) XPS valence band spectra of 500-100-30 and 500-100-24 samples.

surface tension and Coulomb forces acting on the surface, which induced the formation of nanorods from disordered structures [25]. In the calcination process, the oxygen vacancy formation process through the removal of hydroxyl groups occurs prior to the generation of Ti-O-Ti bonds via a dehydration process of $\mathrm{Ti}-\mathrm{OH}$ groups. The reason is probably due to the presence of oxygen vacancies which may direct the formation of Ti-O-Ti bonds.

Fig. 4 shows the ultraviolet-visible (UV-Vis) absorbance spectra of freshly prepared samples. According to the results of 500-100-24 and 500-100-30 samples, the absorbance increased with higher $\mathrm{Ti}^{3+}$ content, which might also correlate with better photocatalytic activity. Hydrogen production from water splitting was performed to investigate the photocatalytic activity of the as-prepared samples, as shown in Fig. 5(a). Compared with the 500-100-12 samples, the 100-12 sample did not show any discernable photocatalytic activity, likely because of its poor crystallinity. On the basis of the results for 500-0-12, 500-20-12, 500-50-12, and 500-100-12 samples, the amount of $\mathrm{H}_{2} \mathrm{O}_{2}$ added during their synthesis was an important factor determining the photocatalytic activity thorough its control over the amounts of oxygen vacancies in the samples. However, there seemed to be certain oxygen vacancy content for optimal photocatalytic activity because further increases of oxygen vacancies at longer hydrothermal times (sample 500-100-30) decreased the activity. According to theoretical calculations [16,26-30], oxygen vacancies tend to elevate the valence band maximum (VBM) $0.4 \mathrm{~V}$ higher than that of normal titania by forming a tail in the density of states, which is generally favorable for catalytic activity. Fig. 5(b) shows valence band (VB) XPS of 500-100-24 and 500-100-30 samples. The VB XPS of 500-100-24 shows that the main absorption onset was located at $2.16 \mathrm{eV}$ below the Fermi energy, whereas the maximum energy associated with the band tail blue-shifted further toward the vacuum level at approximately $1.7 \mathrm{eV}$. The values of 500-100-30 were 2.62 and $2.02 \mathrm{eV}$, respectively. For the 500-100-24 sample, the tail was approximately $0.46 \mathrm{eV}$ above the VBM which was consistent with the theoretical value that should result in better photocatalysis. Furthermore, oxygen vacancies also introduce localized states below the conduction band (CB) minimum [30,31], and the width of the vacancy band increased together with the concentration of vacancies. Large amounts of oxygen vacancies in the 500-100-30 samples likely shifted the vacancy band to special location below the CB, resulting in low mobility of the electrons at these levels and their becoming electron/hole recombination centers. These findings resemble results for reduced rutile titania [27,29]. Therefore, an optimal oxygen vacancy level exists for these samples.

\section{Conclusions}

In summary, $\mathrm{Ti}^{3+}$ self-doped anatase titania was prepared by removing hydroxyl groups through high temperature calcination. When the amount of $\mathrm{H}_{2} \mathrm{O}_{2}$ was $100 \mu \mathrm{L}$ and the hydrothermal reaction time reached $12 \mathrm{~h}$, appropriate oxygen vacancy defects formed after calcining in a $\mathrm{N}_{2}$ atmosphere. These defects enabled dehydration of $\mathrm{Ti}-\mathrm{OH}$ along one direction through a change of the surface tension and Coulomb forces to form nanorod structures from the disordered structure. Based on our EPR and morphology studies, we deduced that hydroxyl groups were removed prior to the dehydration process. Comparing the 500-100-24 with 500-100-30 samples, we found that more oxygen vacancies can improve visible-light absorption but do not necessarily contribute to photocatalytic activity. The VB of the samples determined by XPS and previous calculations suggested that these findings can be ascribed to the following: (1) The tail of the VBM was approximately $0.46 \mathrm{eV}$ above the VBM of 500-100-24, which was consistent with the theoretical value believed to contribute to enhanced photocatalysis; (2) more oxygen vacancies in the 500-100-30 samples likely caused the vacancy band width reaching to special location below $\mathrm{CB}$, where it acted as an electron/hole recombination center.

\section{References}

[1] Z. G. Zou, J. H. Ye, K. Sayama, H. Arakawa, Nature, 2001, 414, 625-627. 


\section{Graphical Abstract}

Chin. J. Catal., 2018, 39: 510-516 doi: 10.1016/S1872-2067(17)62968-1

A new approach to inducing $\mathrm{Ti}^{3+}$ in anatase $\mathrm{TiO}_{2}$ for efficient photocatalytic hydrogen production

Shunhang Wei, Shuang $\mathrm{Ni}^{*}$, Xiaoxiang Xu*

Tongji University; Laser Fusion Research Center, China Academy of Engineering Physics
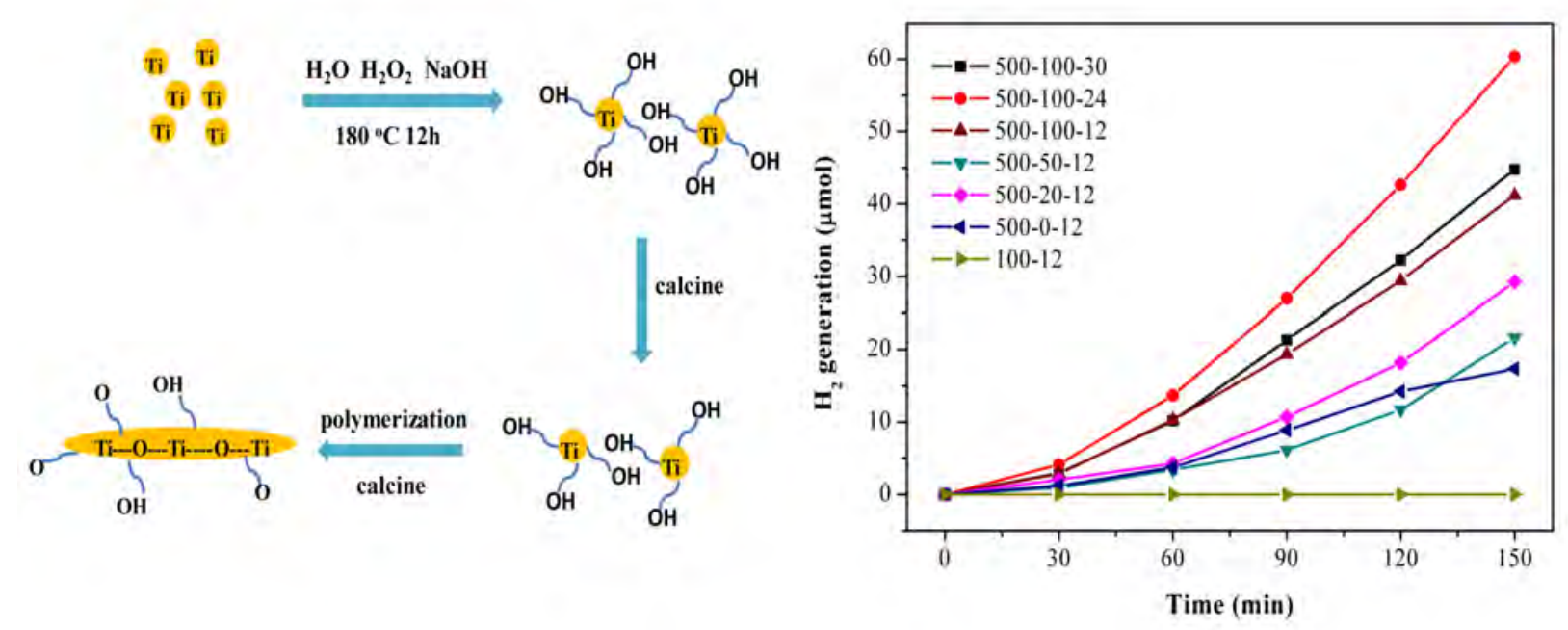

In the synthesis of $\mathrm{TiO}_{2}$, the amount of a $\mathrm{H}_{2} \mathrm{O}_{2}$ precursor and hydrothermal reaction time were adjusted to show that the highest photocatalytic hydrogen production activity featured an optimal oxygen vacancy content.

[2] M. Gratzel, Nature, 2001, 414, 338-344.

[3] X. X. Xu, C. Randorn, P. Efstathiou, J. T. S. Irvine, Nature Mater., 2012, 11, 595-598.

[4] C. Xue, H. An, X. Q. Yan, J. L. Li, B. L. Yang, J. J. Wei, G. D. Yang, Nano Energy, 2017, 39, 513-523.

[5] B. Lin, H. An, X. Q. Yan, T. X. Zhang, J. J. Wei, G. D. Yang, Appl. Catal. $B, 2017,210,173-183$.

[6] B. Lin, H. Li, H. An, W. B. Hao, J. J. Wei, Y. Z. Dai, C. S. Ma, G. D. Yang, Appl. Catal. B, 2018, 220, 542-552.

[7] X. B. Chen, S. H. Shen, L. J. Guo, S. S. Mao, Chem. Rev., 2010, 110, 6503-6570.

[8] L. Liu, X. B. Chen, Chem. Rev., 2014, 114, 9890-9918.

[9] S. H. Wei, R. Wu, J. K. Jian, F. J. Chen, Y. F. Sun, Dalton Trans., 2015, 44, 1534-1538.

[10] H. Irie, Y. Watanabe, K. Hashimoto, Chem. Lett., 2003, 32, 772-773.

[11] J. C. Yu, J. G. Yu, W. K. Ho, Z. T. Jiang, L. Z. Zhang, Chem. Mater., 2002, 14, 3808-3816.

[12] T. Ohno, M. Akiyoshi, T. Umebayashi, K. Asai, T. Mitsui, M. Matsumura, Appl. Catal. A, 2004, 265, 115-121.

[13] H. Irie, Y. Watanabe, K. Hashimoto, J. Phys. Chem. B, 2003, 107, 5483-5486.

[14] X. B. Chen, L. Liu, P. Y. Yu, S. S. Mao, Science, 2011, 331, 746-750.

[15] Z. Wang, C. Y. Yang, T. Q. Lin, H. Yin, P. Chen, D. Y. Wan, F. F. Xu, F. Q. Huang, J. H. Lin, X. M. Xie, M. H. Jiang, Adv. Funct. Mater., 2013, 23, 5444-5450.

[16] Z. Wang, C. Y. Yang, T. Q. Lin, H. Yin, P. Chen, D. Y. Wan, F. F. Xu, F. Q. Huang, J. H. Lin, X. M. Xie, M. H. Jiang, Energy Environ. Sci., 2013,

\section{6, 3007-3014.}

[17] X. Liu, S. M. Gao, H. Xu, Z. Z. Lou, W. J. Wang, B. B. Huang, Y. Dai, Nanoscale, 2013, 5, 1870-1875.

[18] C. Xu, Y. Song, L. F. Lu, C. W. Cheng, D. F. Liu, X. H. Fang, X. Y. Chen, X. F. Zhu, D. D. Li, Nanoscale Res. Lett., 2013, 8, 391/1-391/7.

[19] Z. X. Pei, L. Y. Ding, H. Lin, S. X. Weng, Z. Y. Zheng, Y. D. Hou, P. Liu, J. Mater. Chem. A, 2013, 1, 10099-10102.

[20] H. M. Chen, Y. H. Xie, X. Q. Sun, M. L. Lv, F. F. Wu, L. Zhang, L. Li, X. X. Xu, Dalton Trans., 2015, 44, 13030-13039.

[21] C. Y. Xu, P. X. Zhang, L. Yan, J. Raman Spectrosc., 2001, 32, 862-865.

[22] H. L. Cui, W. Zhao, C. Y. Yang, H. Yin, T. Q. Lin, Y. F. Shan, Y. Xie, H. Gu, F. Q. Huang, J. Mater. Chem. A, 2014, 2, 8612-8616.

[23] L. B. Xiong, J. L. Li, B. Yang, Y. Yu, J. Nanomater., 2012, 831524/1-831524/13.

[24] S. H. Wei, R. Wu, X. X. Xu, J. K. Jian, H. X. Wang, Y. F. Sun, Chem. Eng. J., 2016, 299, 120-125.

[25] S. Zhang, L. M. Peng, Q. Chen, G. H. Du, G. Dawson, W. Z. Zhou, Phys. Rev. Lett., 2003, 91, 256103/1-256103/4.

[26] H. Pan, Y. W. Zhang, V. B. Shenoy, H. J. Gao, J. Phys. Chem. C, 2011, 115, 12224-12231.

[27] D. C. Cronemeyer, Phys. Rev., 1959, 113, 1222-1226.

[28] D. C. Cronemeyer, M. A. Gilleo, Phys. Rev., 1951, 82, 975-976.

[29] I. Justicia, P. Ordejon, G. Canto, J. L. Mozos, J. Fraxedas, G. A. Battiston, R. Gerbasi, A. Figueras, Adv. Mater., 2002, 14, 1399-1402.

[30] F. Zuo, L. Wang, T. Wu, Z. Y. Zhang, D. Borchardt, P. Y. Feng, J. Am. 
Chem. Soc., 2010, 132, 11856-11857.

[31] A. Naldoni, M. Allieta, S. Santangelo, M. Marelli, F. Fabbri, S. Cap- pelli, C. L. Bianchi, R. Psaro, V. Dal Santo, J. Am. Chem. Soc., 2012, 134, 7600-7603

\title{
一种将三价钛引入锐钛型二氧化钛的新方法: 用于有效的光催化产氢
}

\author{
位顺航 ${ }^{a}$, 倪爽 ${ }^{b}{ }^{*}$, 徐晓翔 ${ }^{a, \#}$ \\ a 同济大学化学科学与工程学院, 上海市化学品分析、风险评估与控制重点实验室, 上海200092 \\ b 中国工程物理研究院, 激光聚变研究中心, 等离子体物理国家重点实验室, 四川绵阳621900
}

\begin{abstract}
摘要: 伴随着科技的日益进步, 人们的生活水平有了极大的提升, 但是随之而来的环境污染问题也成为当前世界亟待解决 的重大问题之一. 太阳能是地球上最大的清洁能源来源, 有效地利用太阳能将为解决环境污染问题提供巨大的帮助. 而光 催化技术的一个关键材料就是催化剂, 催化剂对太阳能利用的好坏也就决定了光催化技术的应用前景. 因此, 人们对催化 剂的研究也在逐步深入. 1972年, Fuiishima和Honda在Nature杂志上首次报道了二氧化钛电极在紫外光照射下分解水产生 氢气的现象,自此掀起了半导体光催化的研究热潮.

二氧化钛因具有无毒、廉价和耐腐蚀等优点而在光催化领域广受关注. 传统白色二氧化钛具有两大劣势(宽的禁带宽 度与高的电子(空穴复合率)大大限制了它的应用. 人们对于改变二氧化钠性质进行了大量的尝试, 例如金属/非金属掺杂、 形貌的改变等. 黑色二氧化钠(存在大量的氧空位和三价钛)的出现极大地克服了传统白色二氧化钛的缺点, 其具有窄的禁 带宽度和低的电子/空穴复合速度. 目前, 黑色二氧化钛的制备方法大致分为以下几种: (1)高压下氢化; (2)高温常压下氢 化; (3)铝热还原法; (4)溶液蒸发法; (5)化学氧化法; (6)电化学还原等. 由于更简单安全(不涉及氢气使用)和更好的可见光 光催化活性, 三价钛自掺杂的二氧化钛从这些方法中脱颖而出. 迄今为止, 诱导三价钛的方法通常是能量密集型的, 涉及 不稳定的 $\mathrm{Ti}$ 原料(如 $\mathrm{TiO}$ 和 $\mathrm{TiH}_{2}$ ). 研究用于制备三价钛自掺杂二氧化钛的新方法是十分必要的.

我们以稳定的钛粉为原料, 通过简单的方法将三价钛和氧空位成功地引入锐钛型二氧化钛. 通过 X射线衍射、场致发 射扫描电子显微镜等技术研究了制备样品的物理化学性质, 发现 $\mathrm{H}_{2} \mathrm{O}_{2}$ 和水热反应时间对纳米棒型微观形貌的形成至关重 要. 通过调整诸如 $\mathrm{H}_{2} \mathrm{O}_{2}$ 量和水热反应时间的参数, 根据实验结果提出了形成这种微观结构的可能机制. 更重要的是, 可见 光区域的光吸收受到样品中氧空位量的控制, 存在氧空位的最佳值使光催化产氢活性最高.
\end{abstract}

关键词: 三价钛; 氧空位; 二氧化钛; 光催化剂; 产氢

收稿日期: 2017-09-28. 接受日期: 2017-10-30. 出版日期: 2018-03-05.

*通讯联系人. 电子信箱: nishuang@163.com

\#通讯联系人. 电话/传真: (021)65956919; 电子信箱: xxxu@tongji.edu.cn

基金来源: 国家自然科学基金青年科学基金(21401142); 国家千人计划; 上海市科委(14DZ2261100).

本文的电子版全文由Elsevier出版社在ScienceDirect上出版(http://www.sciencedirect.com/science/journal/18722067). 